\title{
ANALISIS PERBANDINGAN KEUNTUNGAN DAN RISIKO USAHA PERIKANAN RAKYAT SISTEM MONOKULTUR DAN POLIKULTUR DI KABUPATEN PANGKEP
}

\section{Comparative Analysis of Benefits And Risks of Fisheries Business With Monoculture and Policultural Systems in Pangkep Regency}

\author{
Tsalis Kurniawan Husain ${ }^{1}$, Jangkung Handoyo Mulyo ${ }^{2,3}$, Jamhari ${ }^{2}$ \\ ${ }^{1}$ Dosen Program Studi Agribisnis, Fakultas Pertanian, Universitas Muslim Indonesia \\ ${ }^{2}$ Dosen Departemen Sosial Ekonomi Pertanian, Fakultas Pertanian, UGM \\ ${ }^{1,2}$ Jalan Flora, Bulaksumur, Yogyakarta 55281 \\ ${ }^{3}$ Peneliti Pusat Studi Kependudukan dan Kebijakan UGM \\ Gedung Masri Singarimbun, Jalan Tevesia, Bulaksumur, Yogyakarta 55281 \\ tsalis.kurniawan@umi.ac.id
}

Diterima tanggal : 10 September 2016 ; Disetujui tanggal : 11 Oktober 2016

\begin{abstract}
The purpose of this research is to analyze and compare the cost, profit, and risk of monoculture and polyculture fisheries system in Pangkep Regency. The sample collection uses the snowball sampling method. There are 80 fish farmers who were interviewed in this research. The cost and income is analyzed by income analysis, while to measure the level of business risk, Coefficients Variation (CV) analysis is used. To test the hypothesis, analysis of z distribution test is used. The research results show that the fishing cost and income of polyculture system is larger than monoculture system, where the cost of each is $R p 14.722 .597$ and Rp 13.191.880 respectively, while their profit is $R p$ 10.285.066 and Rp 6.710.486 each. Polyculture system has cost risk, revenue risk and profit risk is lower than monoculture system with large value of Coefficients Variation (CV) each by 0,11;0,29 and 0,56 for polyculture system and 0.12; 0,37 and 0,88 for monoculture system. The results of the hypothesis showed that there is difference in cost of, revenue, and profit between poliyculture and monoculture system while there is no significance difference for cost risk, revenue risk and profit risk.
\end{abstract}

Keyword: business risk, fisheries, profit.

\section{INTISARI}

Tujuan penelitian ini adalah untuk menganalisis dan membandingkan biaya, keuntungan dan risiko usaha perikanan rakyat sistem monokultur dan polikultur di Kabupaten Pangkep. Metode dasar yang digunakan adalah metode analisis deskriptif. Pengambilan sampel menggunakan metode snowball sampling. Jumlah sampel yang digunakan dalam penelitian ini sebanyak 80 responden petani tambak. Besarnya biaya dan pendapatan dianalisis dengan analisis pendapatan sedangkan untuk mengukur tingkat risiko usaha menggunakan alat analisis koefisien variasi (CV). Untuk menguji kebenaran hipotesis digunakan analisis uji distribusi z. Hasil penelitian menunjukkan bahwa biaya dan pendapatan usaha perikanan rakyat sistem polikultur lebih besar dari usaha perikanan rakyat sistem monokultur dengan biaya masing-masing sebesar Rp 14.722.597 dan Rp 13.191.880 sedangkan keuntungan masing-masing sebesar Rp 10.285.066 dan Rp 6.710.486. Usaha perikanan rakyat sistem 
polikultur memiliki risiko biaya, risiko penerimaan dan risiko keuntungan lebih rendah dibandingkan dengan usaha perikanan rakyat sistem monokutur dengan besar nilai koefisien variasi (CV) masing-masing sebesar 0,$11 ; 0,29$ dan 0,56 untuk usaha perikanan rakyat sistem polikultur dan 0,$12 ; 0,37$ dan 0,88 untuk usaha perikanan rakyat sistem monokultur. Hasil uji hipotesis memperlihatkan terdapat perbedaan biaya,penerimaan, keuntungan yang signifikan antara usaha perikanan rakyat sistem polikultur dan monokultur sedangkan untuk risiko biaya, risiko penerimaan dan risiko keuntungan tidak terdapat perbedaan yang signifikan.

Kata kunci: keuntungan, risiko usaha, usaha perikanan rakyat.

\section{PENDAHULUAN}

Indonesia merupakan negara maritim dengan luas perairan laut mencapai $70 \%$ dari total luas wilayah dan merupakan salah satu Negara yang mempunyai garis pantai terpanjang di dunia. Kondisi ini menjadikan Indonesia sebagai negara yang memiliki potensi besar pada sektor perikanan. Subsektor perikanan merupakan subsektor terbesar kedua penyumbang PDB (Product Domestic Bruto) pada sektor pertanian dengan penigkatan rata-rata sebesar $13,07 \%$ (dari Rp. 177 triliun menjadi Rp. 255 Triliun) dalam periode 2009-2012 (KKP, 2014). Salah satu potensi subsektor perikanan adalah perikanan budidaya. Pengelolaan perikanan budidaya lebih ditekankan pada kegiatan di perairan payau, perairan tawar dan perairan pantai. Komoditas yang banyak dibudidayakan antara lain: udang, ikan bandeng, nila, kerapu, dan rumput laut (KKP,2014). Salah satu komoditas yang sering dibudidayakan adalah ikan bandeng. Ikan bandeng memiliki rasa daging yang gurih dan lembut serta harga yang terjangkau.
Berdasarkan data KKP (2014) Sulawesi Selatan merupakan provinsi posisi kedua dalam produksi ikan bandeng terbanyak di Indonesia pada tahun 2013 dengan jumlah pangsa produksi mencapai $21 \%$ dan salah satu sentra produksi ikan bandeng di Sulawesi Selatan adalah Kabupaten Pangkep. Kabupaten Pangkep memiliki kawasan pesisir sebesar 781,13 kilometer persegi atau $70 \%$ dari luas daratan.

Selain itu, Kabupaten Pangkep memiliki panjang garis pesisir sepanjang 95 kilometer. Sejak tahun 2003, kawasan hutan mangrove di sepanjang kawasan pesisir di Kabupaten Pangkep banyak mengalami konversi menjadi tambak. Luas tambak yang dikembangkan seluas 2.311,32 hektar tambak dengan komoditas utama bandeng dan udang. Kawasan hutan mangrove merupakan ekosistem yang sangat produktif dan berpotensi tinggi untuk dimanfaatkan. Kawasan hutan mangrove bukan sekedar penghasil sumberdaya hutan, tetapi juga sangat berperan dalam menunjang sumberdaya perikanan (Kordi, 2011). 
Kawasan hutan mangrove merupakan kawasan yang sangat ideal untuk budidaya bandeng dan udang. Pada mulanya petani tambak melakukan usaha perikanan dengan sistem monokultur, yaitu dengan melakukan pembesaran untuk satu jenis komoditas saja dalam satu kolam tambak. Seiring pesatnya perkembangan informasi dan teknologi serta meningkatnya permintaan pasar akan komoditas udang, maka petani tambak secara bertahap mencoba usaha perikanan dengan sistem polikultur. Sistem ini memberi kesempatan kepada petani tambak untuk mengelola tambak dengan dua jenis komoditas, yaitu ikan bandeng dan udang.

Monokultur dan polikultur merupakan dua sistem usaha budidaya yang biasa digunakan dalam usahatani di sektor perikanan agar efisien dan memudahkan dalam penggunaan lahan. Sistem usaha budidaya monokultur adalah sistem usaha budidaya dengan menggunakan satu jenis komoditas yang dilakukan sekali atau beberapa kali dalam setahun tergantung jenis komoditasnya. Sistem usaha budidaya polikultur merupakan suatu usaha budidaya dengan membudidayakan dua komoditas atau lebih pada lahan dalam waktu yang sama, yang diatur sedemikian rupa.

Yasin (2013) menjelaskan bahwa polikultur merupakan metode budidaya yang digunakan untuk memelihara banyak komoditas dalam satu lahan, seperti udang, bandeng dan rumput laut. Dengan pemanfaatan lahan yang berluasan sama, masyarakat dapat menambah penghasilannya dari panen produk lain. Hal ini tentu saja sangat membantu peningkatan penghasilan petambak.

Hasil penelitian Dolorosa, et al., (2014) usaha perikanan tambak polikultur bandeng-udang windu di Kecamatan Pamangkat, Jawai, dan Jawai Selatan Kabupaten Sambas layak diusahakan. Penerimaan rata-rata yang diterima oleh petani sebesar Rp 24.126.349 per hektar selama satu tahun, dengan biaya yang dikeluarkan sebesar Rp 11.717.613 per hektar per tahunnya. Keuntungan yang diperoleh sebesar Rp 12.408.736 per hektar selama satu tahun. Sistem polikultur dengan komoditas lainnya pun mendatangkan keuntungan, seperti hasil penelitian Humamy (2013) menunjukkaan bahwa sistem pengelolaan usaha tambak polikultur kepiting-ikan nila dilakukan dengan menggunakan metode campur jenis yang menggunakan kolam tambak sebagai wadah budidaya, dimana pendapatan usaha tambak polikultur adalah menguntungkan dengan tingkat penerimaan, biaya dan pendapatan berturut-turut sebesar $\mathrm{Rp}$ 54.959.039, Rp 30.090.921 dan Rp 24.868.118 per periode.

Studi komparatif yang dilakukan oleh Marban, et al., (2006) dalam penelitiannya tentang simulating the economic viability of Nile tilapia and Australian redclaw crayfish polyculture mengemukakan usaha perikanan sistem 
polikultur lebih menguntungkan dengan penerimaan bersih sebesar $\$ 15.080$ dibanding dengan sistem monokultur sebesar \$11.529. Penelitian terkait analisis komparatif sistem monokultur dan sistem polikultur pada usahatani wortel di Kabupaten Karanganyar, Marwiantin, et al., (2014) menjelaskan bahwa rata-rata biaya dan penerimaan usahatani wortel monokultur yaitu sebesar Rp 33.661.305 dan Rp 73.109.554 sedangkan rata-rata biaya dan penerimaan usahatani wortel polikultur sebesar Rp 62.367.301 dan Rp 168.575.513. Pendapatan usahatani wortel polikultur Rp 106.208.212,69/Ha/MT lebih tinggi daripada pendapatan usahatani wortel monokultur Rp 39.448.248,69/Ha/MT.

Namun berbeda dengan hasil penelitian Mahmud, et al., (2007) di Kabupaten Pinrang, Sulawesi Selatan tentang pengkajian usaha tambak udang windu tradisional yang menunjukkan keuntungan pola budidaya sistem monokultur lebih tinggi sebesar Rp 15.489.000 dibanding dengan pola budidaya polikultur sebesar $\mathrm{Rp}$ 4.365.000. Keuntungan rataan per hektar per tahun yang diperoleh oleh petani tambak udang tradisional dengan pola monokultur lebih tinggi dari pada budidaya pola polikultur, karena tingginya rataan tebaran bibit udang yang dilakukan.

Sistem monokultur maupun polikultur masing-masing memiliki risiko tersendiri dalam pengelolaannya. Salah satu cara paling umum yang dilakukan oleh petani untuk menghindari risiko adalah dengan diversifikasi. Diversifikasi dalam bidang pertanian dapat dilakukan dengan pilihan pola tanam dengan sistem tumpangsari atau polikultur/multikultur. Menyebarkan risiko pada beberapa komoditas diharapkan mampu memberi kompensasi jika salah satu komoditas mengalami kerugian (Ramaswami et.al, 2003).

Diversifikasi usahatani merupakan alternatif yang tepat untuk meminimalkan risiko sekaligus untuk melindungi dari fluktuasi produski (Rifki, 2004). Hal ini sejalan dengan hasil penelitian Imelda, et al., (2008) yang menunjukkan risiko usahatani lidah buaya yang dilakukan dengan pola multikultur memiliki risiko lebih rendah dibandingkan dengan usahatani lidah buaya yang dilakukan dengan pola monokultur.

Adanya sistem polikultur ini diharapkan mampu mendongkrak kesejahteraan petani karena mendapat pemasukan dari dua komoditas yang berbeda tanpa harus menambah jumlah luas lahan. Namun, selain memberi peluang keuntungan yang besar, sistem polikultur juga memiliki risiko yang dapat menggangu perkembangan salah satu komoditas bahkan kedua komoditas dalam proses produksinya. Risiko ini yang membuat beberapa petani enggan meninggalkan sistem monokultur dalam usaha perikanannya. Melihat beberapa fenomena di atas maka peneliti tertarik untuk meneliti tentang studi 
komparatif usaha perikanan rakyat sistem monokultur dan usaha perikanan rakyat sistem polikultur.

Penelitian ini bertujuan untuk (1) Untuk membandingkan biaya, penerimaan dan keuntungan usaha perikanan rakyat sistem monokultur dan sistem polikultur di Kabupaten Pangkep, (2) Untuk membandingkan risiko usaha perikanan rakyat sistem monokultur dan sistem polikultur di Kabupaten Pangkep.

\section{METODE PENELITIAN}

Metode dasar yang digunakan adalah metode deskriptif yang dilakukan di Kecamatan Pangkajene Kabupaten Pangkep Provinsi Sulawesi Selatan dengan pertimbangan bahwa wilayah tersebut merupakan daerah sentra produksi dan potensial pengembangan ikan bandeng dan udang.

Data yang digunakan dalam penelitian ini bersumber dari data primer dan sekunder. Data primer adalah data yang diperoleh dari hasil wawancara dengan 80 responden dalam hal ini adalah petani tambak yang melakukan usaha perikanan rakyat secara monokultur dan secara polikultur, sesuai dengan daftar pertanyaan yang telah disiapkan. Sedangkan data sekunder adalah data-data yang diperoleh dari instansi-instansi terkait yang memiliki keterkaitan dengan penelitian, seperti Badan Pusat Statistik, Dinas Kelautan dan Perikanan, dan instansi terkait lainnya.
Metode untuk menjawab tujuan pertama menggunakan analisis biaya dan keuntungan sebagai berikut (Adi, 2011)

1. Biaya

$$
\mathrm{TC}=\mathrm{TFC}+\mathrm{TVC}
$$

2. Penerimaan

$\mathrm{TR}=\mathrm{Y}$. Py

3. Keuntungan

$$
\begin{array}{ll}
\boldsymbol{\pi} & =\mathrm{TR}-\mathrm{TC}_{\mathrm{E}+\mathrm{I}} \\
\boldsymbol{\pi} & =\mathrm{TR}-(\mathrm{TVC}+\mathrm{TFC})_{\mathrm{E}+\mathrm{I}} \\
\boldsymbol{\pi} & =\mathrm{Py} \cdot \mathrm{Y}-(\mathrm{Px} \cdot \mathrm{X}+\mathrm{TFC})_{\mathrm{E}+\mathrm{I}}
\end{array}
$$

Keterangan :

$$
\begin{array}{ll}
\boldsymbol{\pi} & =\text { Keuntungan } \\
\mathrm{TR} & =\text { Penerimaan Total } \\
\mathrm{TC}_{\mathrm{E}+\mathrm{I}} & =\text { Biaya Total }_{\text {Eksplisit }+ \text { Implisit }} \\
\mathrm{TFC} & =\text { Biaya Tetap Total } \\
\mathrm{TVC} & =\text { Biaya Variabel Total } \\
\mathrm{Py} & =\text { Harga Output } \\
\mathrm{Y} & =\text { Jumlah Input } \\
\mathrm{Px} & =\text { Harga Input } \\
\mathrm{X} & =\text { Jumlah Input }
\end{array}
$$

Pengukuran risiko dapat menggunakan analisis koefisien variasi dimana dalam perhitungannya terlebih dahulu menghitung nilai variasi dan standar deviasi. Semakin kecil nilai koefisien variasi maka semakin kecil risiko yang dihadapi, sebaliknya semakin besar nilai koefisien variasi maka semakin besar risiko yang dihadapi. Adapun rumus dalam menghitung koefisien variasi untuk menjawab tujuan kedua menurut Kurniati (2011) adalah sebagai berikut : 


$$
\begin{aligned}
& \text { Risiko biaya }: C V=\frac{\sigma c}{C r} \\
& \text { Risiko penerimaan : } C V=\frac{\sigma r}{R r} \\
& \text { Risiko keuntungan : } C V=\frac{\sigma y}{Y r}
\end{aligned}
$$

Keterangan :

$$
\begin{aligned}
\mathrm{CV} & =\text { Koefisien variasi } \\
\sigma \mathrm{c} & =\text { Standar deviasi biaya } \\
\sigma \mathrm{r} & =\text { Standar deviasi penerimaan } \\
\sigma \mathrm{y} & =\text { Standar deviasi keuntungan } \\
\mathrm{Cr} & =\text { Nilai rata-rata biaya } \\
\mathrm{Rr} & =\text { Nilai rata-rata penerimaan } \\
\mathrm{Yr} & =\text { Nilai rata-rata keuntungan }
\end{aligned}
$$

Untuk mengetahui perbedaan antara usaha perikanan rakyat sistem monokultur dan polikultur di Kabupaten Pangkep, maka dilakukan uji komparasi dengan menggunakan uji statistik menggunakan distribusi z (Hasan, 2008). Prosedur pengujian hipotesisnya sebagai berikut.

a. Menentukan hipotesis yang akan diuji, yaitu:

$\mathrm{H}_{0}: \mu_{\mathrm{p}}=\mu_{\mathrm{m}}$, artinya biaya, penerimaan, keuntungan dan risiko usaha perikanan rakyat sistem polikultur tidak terdapat perbedaan nyata dengan biaya, penerimaan, keuntungan dan risiko usaha perikanan rakyat sistem monokultur .

$\mathrm{H}_{\mathrm{a}}: \mu_{\mathrm{p}} \neq \mu_{\mathrm{m}}$, artinya biaya, penerimaan, keuntungan dan risiko usaha perikanan rakyat sistem polikultur terdapat perbedaan nyata dengan dari biaya, penerimaan, keuntungan dan risiko usaha perikanan rakyat sistem monokultur. b. Menentukan nilai z tabel.

c. Mencari nilai $z$ hitung dengan formula sebagai berikut (Hasan, 2008).

$z_{0}=\frac{\overline{X_{1}}-\overline{X_{2}}}{s_{\bar{x}_{1}-\bar{x}_{2}}}$

dengan $\sigma_{\bar{x}_{1}-\bar{x}_{2}}=\sqrt{\frac{s_{1}^{2}}{n_{1}}+\frac{s_{2}^{2}}{n_{2}}}$

d. Kriteria pengujian adalah sebagai berikut

- Jika nilai $\mathrm{z}$ hitung $>\mathrm{z}$ tabel

- Berarti $\mathrm{H}_{\mathrm{a}}$ diterima dan $\mathrm{H}_{0}$ ditolak, artinya bahwa secara statistik biaya, penerimaan, keuntungan dan risiko usaha perikanan rakyat sistem polikultur terdapat perbedaan yang nyata dengan biaya, penerimaan, keuntungan dan risiko usaha perikanan rakyat sistem monokultur.

- Jika nilai $\mathrm{z}$ hitung $<\mathrm{z}$ tabel: Berarti $\mathrm{H}_{\mathrm{o}}$ diterima dan $\mathrm{H}_{\mathrm{a}}$ ditolak artinya bahwa secara statistik biaya, penerimaan, keuntungan dan risiko usaha perikanan rakyat sistem polikultur tidak terdapat perbedaan yang nyata dengan biaya, penerimaan, keuntungan dan risiko usaha perikanan rakyat sistem monokultur .

\section{HASIL DAN PEMBAHASAN}

Petani tambak yang dijadikan responden dalam penelitian ini merupakan petani tambak pemilik lahan yang masih 
aktif melakukan usaha perikanan rakyat. Total jumlah responden dalam penelitian ini berjumlah 80 orang yang terdiri masingmasing 40 orang untuk usaha perikanan rakyat, baik monokultur maupun polikultur.

Tabel 1. Rata-Rata Luas Lahan dan Jumlah Tebaran Pada Usaha Perikanan Rakyat Sistem Monokultur dan Polikultur di Kabupaten Pangkep.

\begin{tabular}{lcc}
\hline \multirow{2}{*}{ Uraian } & \multicolumn{2}{c}{ Usaha Perikanan Rakyat } \\
\cline { 2 - 3 } & Monokultur & Polikultur \\
\hline Luas Lahan (ha) & 1,8 & 1,9 \\
Jumlah Tebaran & & \\
(ekor) & & \\
- Ikan Bandeng & 8.562 & 7.722 \\
- Udang & - & 19.805 \\
\hline
\end{tabular}

Sumber: Analisis Data Primer, 2015

Tabel 1 menampilkan rata-rata luas lahan petani tambak sebesar 1,8 ha untuk usaha perikanan rakyat sistem monokultur dan 1,9 ha untuk usaha perikanan rakyat sistem polikultur. Adapun rata-rata jumlah tebaran ikan bandeng pada usaha perikanan rakyat sistem monokultur sebanyak 8.562 ekor/ha sedangkan rata-rata jumlah tebaran ikan bandeng pada usaha perikanan rakyat sistem polikultur sebanyak 7.722 ekor/ha dan rata-rata jumlah tebaran udang pada lahan yang sama sebanyak 19.805 ekor/ha.

\section{Biaya Investasi}

Usaha perikanan rakyat memerlukan biaya investasi dalam menjalankan kegiatan usahanya meliputi peralatan budidaya. Biaya investasi per tahun terhitung sebagai biaya penyusutan. Biaya penyusutan adalah biaya yang dikeluarkan akibat penurunan nilai dari suatu alat atau mesin akibat dari pertambahan umur pemakaian. Biaya penyusutan diambil dari penurunan nilai peralatan budidaya yang digunakan. Berdasarkan perincian biaya penyusutan terlihat bahwa nilai sisa dianggap tidak ada dikarenakan petambak kebanyakan tidak menjual kembali investasi yang dimiliki dalam waktu lama hingga nilai fungsinya habis. Biaya investasi rata-rata yang dikeluarkan dalam kegiatan usaha perikanan rakyat sistem monokultur dan sistem polikultur dengan luas tambak 1 ha adalah masing-masing sebesar $\mathrm{Rp}$ 21.050.285 dan $\mathrm{Rp} 21.820 .798$. Adapun perbedaan biaya investasi disebabkan karena pada usaha perikanan sistem polikultur melakukan peremajaan tambak dimana sebelumnya tambak digunakan untuk usaha perikanan rakyat sistem monokultur.

Biaya investasi yang dikeluarkan oleh petani tambak direalisasikan dalam bentuk investasi peralatan untuk mendukung kegiatan usaha yang dilakukan. Tidak semua petani tambak memiliki peralatan yang memadai, hanya jala dan pembuatan tanggul tambak yang seluruh petani tambak memilikinya. Petambak biasanya meminjam peralatan ke petambak lainnya atau tengkulak pasar lelang yang disebut punggawa. Rincian biaya investasi disajikan pada tabel 2. 
Tabel 2. Rata-Rata Biaya Investasi Usaha Perikanan Rakyat Sistem Monokultur dan Polikultur di Kabupaten Pangkep

\begin{tabular}{llrccc}
\hline \multirow{2}{*}{ No } & \multirow{2}{*}{ Jenis investasi } & \multicolumn{3}{c}{ Biaya Usaha Perikanan Rakyat } \\
\cline { 3 - 6 } & & \multicolumn{2}{c}{ Monokultur } & \multicolumn{2}{c}{ Polikultur } \\
\cline { 2 - 6 } & Pompa & $(\%)$ & $(\mathrm{Rp})$ & $(\%)$ \\
\hline 1. & Pompa & 2.715 .000 & 13 & 2.650 .000 & 12 \\
2. & Jala & 401.250 & 2 & 417.500 & 2 \\
3. & Pukat & 411.667 & 2 & 401.563 & 2 \\
4. & Keranjang & 677.375 & 3 & 617.875 & 3 \\
5. & Tanggul Tambak & 16.844 .993 & 80 & 17.733 .860 & 81 \\
\hline & \multicolumn{1}{c}{ Total } & 21.050 .285 & 100 & 21.820 .798 & 100 \\
\hline
\end{tabular}

Sumber: Analisis Data Primer, 2015

\section{Biaya Variabel}

Biaya variabel yang dibutuhkan petani tambak untuk menjalankan kegiatan usaha meliputi biaya benih, biaya pupuk, biaya pakan, obat-obatan, Bahan bakar minyak, upah tenaga kerja dan biaya transportasi. Petani tambak mendapatkan benih dari pembenihan yang berada di Kabupaten Pangkep, Barru, Maros dan Takalar. Biaya Pengangkutan benih tidak ada karena benih yang diambil dari luar sudah termasuk didalam harga benih ikan dan udang secara keseluruhan. Biaya variabel rata-rata yang dikeluarkan dalam kegiatan usaha perikanan rakyat sistem monokultur dan sistem polikultur dengan luas tambak 1 ha adalah masing-masing sebesar Rp 3.828.949 dan Rp 5.062.921 per tahun. Rincian biaya variabel disajikan pada tabel 3 .

Biaya tenaga kerja menjadi biaya variabel terbesar dikarenakan sebagian besar petambak memberlakukan sistem bagi hasil sebesar $10 \%$ dari selisih antara penerimaan dan biaya yang dikeluarkan selama masa produksi.
Petambak lebih mengandalkan pakan alami yang dihasilkan oleh pupuk yang digunakan pada tambak, sehingga tidak semua petani mengeluarkan biaya pakan. Biaya obat-obatan usaha perikanan rakyat sistem monokultur lebih besar dibanding dengan sistem polikultur karena tebaran bandeng pada sistem monokultur lebih banyak dibanding dengan sistem polikultur, dimana padat tebaran mempengaruhi berkembangnya penyakit yang dapat menyerang komoditas ikan. Sistem polikultur terbantu dengan adanya komoditas udang yang berfungsi sebagai pompa alami dan dapat saling memanfaatkan sehingga terjadi sirkulasi dalam satu lokasi budidaya dan mengurangi penggunaan BBM sebagai bahan bakar pompa air.

\section{Biaya Tetap}

Biaya tetap yang digunakan oleh petambak pada usaha perikanan meliputi biaya sewa tambak, biaya perawatan tambak dan bunga modal. Berdasarkan tabel 5 besarnya biaya tetap rata-rata yang 
Tabel 3. Rata-Rata Biaya Variabel Usaha Perikanan Rakyat Sistem Monokultur dan Polikultur di Kabupaten Pangkep

\begin{tabular}{|c|c|c|c|c|c|}
\hline \multirow{3}{*}{ No. } & \multirow{3}{*}{ Uraian } & \multicolumn{4}{|c|}{ Biaya Usaha Perikanan Rakyat } \\
\hline & & \multicolumn{2}{|c|}{ Monokultur } & \multicolumn{2}{|c|}{ Polikultur } \\
\hline & & $(\mathrm{Rp})$ & $(\%)$ & $(\mathrm{Rp})$ & $(\%)$ \\
\hline \multirow[t]{3}{*}{1.} & Benih & & & & \\
\hline & -Bandeng & 445.988 & 12 & 390.382 & 8 \\
\hline & -Udang & - & - & 889.592 & 18 \\
\hline 2. & Pupuk & 721.125 & 19 & 720.356 & 14 \\
\hline 3. & Pakan & 105.066 & 3 & 118.165 & 2 \\
\hline 4. & Obat-obatan & 164.812 & 4 & 163.043 & 3 \\
\hline 5. & BBM & 49.868 & 1 & 42.825 & 1 \\
\hline 6. & Transportasi & 133.745 & 3 & 138.340 & 3 \\
\hline \multirow[t]{2}{*}{7.} & Tenaga kerja & 2.208 .345 & 58 & 2.600 .219 & 51 \\
\hline & Total & 3.828 .949 & 100 & 5.062 .921 & 100 \\
\hline
\end{tabular}

Sumber: Analisis Data Primer, 2015

Tabel 4. Rata-Rata Biaya Tetap Usaha Perikanan Rakyat Sistem Monokultur dan Polikultur di Kabupaten Pangkep

\begin{tabular}{lrccc}
\hline \multirow{1}{*}{ Uraian } & \multicolumn{4}{c}{ Biaya Usaha Perikanan Rakyat } \\
\cline { 2 - 5 } & \multicolumn{2}{c}{ Monokultur } & \multicolumn{2}{c}{ Polikultur } \\
\cline { 2 - 5 } & $(\mathrm{Rp})$ & $(\%)$ & $(\mathrm{Rp})$ & $(\%)$ \\
\hline Sewa tambak & 4.237 .311 & 45 & 4.279 .974 & 44 \\
Biaya perawatan & 77.250 & 1 & 106.625 & 1 \\
Bunga modal & 2.211 .211 & 24 & 2.388 .633 & 25 \\
Biaya penyusutan & 2.837 .159 & 30 & 2.885 .344 & 30 \\
\hline \multicolumn{1}{c}{ Total } & 9.362 .931 & 100 & 9.660 .576 & 100 \\
\hline \multicolumn{1}{c}{} & \multicolumn{5}{c}{} \\
\hline
\end{tabular}

Sumber: Analisis Data Primer, 2015

dikeluarkan dalam kegiatan usaha perikanan rakyat sistem monokultur dan polikultur untuk tambak dengan luas tambak sebesar 1 ha adalah masing-masing sebesar $\mathrm{Rp}$ 9.362.931dan $\operatorname{Rp} 9.660 .576$ per tahun.

\section{Analisis Keuntungan}

Keuntungan kegiatan usaha perikanan rakyat di Kabupaten Pangkep diperoleh dari selisih antara total penerimaan dengan total biaya (biaya eksplisist dan implisit) yang dikeluarkan pada saat melakukan kegiatan usaha perikanan. Berdasarkan pada tabel 5 besarnya penerimaan ratarata yang didapatkan pada kegiatan usaha perikanan rakyat sistem monokultur dan polikultur dengan luas tambak sebesar 1 ha adalah masing-masing sebesar Rp 19.902.366 dan Rp 25.008.564 per tahun. Rincian penerimaan usaha perikanan rakyat dapat dilihat pada tabel 5.

Penerimaan usaha perikanan rakyat lebih besar dari biaya produksi yang dikeluarkan untuk melakukan kegiatan usaha perikanan rakyat, besarnya keuntungan rata-rata yang didapatkan dalam kegiatan 
Tabel 5. Rata-Rata Penerimaan Usaha Perikanan Rakyat Sistem Monokultur dan Polikultur di Kabupaten Pangkep

\begin{tabular}{llccc}
\hline \multirow{3}{*}{ Uraian } & \multicolumn{3}{c}{ Penerimaan Usaha Perikanan Rakyat (Rp) } \\
\cline { 2 - 5 } & \multicolumn{3}{c}{ Monokultur } & \multicolumn{3}{c}{ Polikultur } \\
\cline { 2 - 5 } & $(\mathrm{Rp})$ & $(\%)$ & $(\mathrm{Rp})$ & $(\%)$ \\
\hline $\begin{array}{l}\text { Ikan Bandeng } \\
\text { Udang }\end{array}$ & 19.902 .366 & 100 & 19.335 .639 & 77 \\
\hline \multicolumn{1}{c}{ Total } & - & & 5.672 .925 & 23 \\
\hline
\end{tabular}

Sumber: Analisis Data Primer, 2015

Tabel 6. Rata-Rata Keuntungan Usaha Perikanan Rakyat Sistem Monokultur dan Polikultur di Kabupaten Pangkep

\begin{tabular}{|c|c|c|c|}
\hline \multirow{2}{*}{ Uraian } & \multicolumn{2}{|c|}{ Usaha Perikanan Rakyat (Rp) } & \multirow{2}{*}{ Z Hitung } \\
\hline & Monokultur & Polikultur & \\
\hline Penerimaan & 19.902 .366 & 25.008 .564 & $3,49 * *$ \\
\hline Biaya pembesaran & & & $4,79 * *$ \\
\hline a. Biaya Variabel & $(3.828 .949)$ & $(5.062 .921)$ & \\
\hline b. Biaya Tetap & $(9.362 .931)$ & $(9.660 .576)$ & \\
\hline Keuntungan & 6.710 .486 & 10.285 .066 & $2,77 * *$ \\
\hline
\end{tabular}

Sumber: Analisis Data Primer, 2015

usaha perikanan rakyat sistem monokultur dan polikultur dengan luas tambak sebesar 1 ha adalah masing-masing sebesar Rp 6.710.486 dan Rp 10.285.066 per tahun. Tabel 6 menunjukkan keuntungan usaha perikanan rakyat sistem polikultur lebih besar dibanding dengan keuntungan usaha perikanan rakyat sistem monokultur. Hasil perhitungan $\mathrm{z}$ tes pada tabel 6 menujukkan bahwa biaya, penerimaan dan keuntungan usaha perikanan rakyat sistem polikultur terdapat perbedaan yang nyata dengan biaya, penerimaan dan keuntungan usaha perikanan sistem monokultur di Kabupaten Pangkep karena nilai z hitungnya lebih besar dari z tabel.

Keuntungan usaha perikanan rakyat ini masih jauh dari Upah Minimum Provinsi Sulawesi Selatan dimana menurut Surat
Keputusan Gubernur Sulawesi Selatan Nomor 2060/X/Tahun 2014 tentang Upah Minimum Provinsi tahun 2015 di daerah Sulawesi Selatan, tertanggal 17 Oktober 2014 telah terbit dan berlaku sejak tanggal 1 Januari 2015 upah minimum Provinsi Sulawesi Selatan pada tahun 2015 sebesar Rp 2.000.000. Sebagian besar petambak di Kabupaten Pangkep hanya menempatkan kegiatan usaha perikanan rakyat sebagai pekerjaan sampingan dan hanya beberapa petambak yang menjadikan pekerjaan utama untuk menopang kebutuhan seharihari.

\section{Analisis Risiko}

Risiko dianalisis menggunakan koefisien variasi (CV). Biasanya besarnya nilai koefisien variasi menunjukkan 
Tabel 7. Perbandingan Risiko Biaya, Risiko Penerimaan dan Risiko Keuntungan Usaha Perikanan Rakyat Sistem Monokultur dan Polikultur di Kabupaten Pangkep.

\begin{tabular}{lccc}
\hline \multirow{2}{*}{ Uraian } & \multicolumn{2}{c}{ Usaha Perikanan Rakyat } & \multirow{2}{*}{ Z Hitung } \\
\cline { 2 - 3 } & Monokultur & Polikultur & $0,93^{\text {ns }}$ \\
CV Biaya & 0,12 & 0,11 & $0,50^{\text {ns }}$ \\
CV Penerimaan & 0,37 & 0,29 & $0,14^{\text {ns }}$ \\
\hline
\end{tabular}

Sumber: Analisis Data Primer, 2015

besarnya risiko relatif usahatani. Nilai koefisien variasi yang kecil menunjukkan variabilitas nilai rata-rata pada karakteristik tersebut rendah. Hal ini menunjukkan risiko yang dihadapi petani untuk biaya, penerimaan dan keutungan rata-rata tersebut kecil. Perbandingan risiko usaha antar usaha perikanan rakyat sistem monokultur dan polikultur dapat dilihat pada tabel 7.

Risiko dianalisis menggunakan koefisien variasi dan dilakukan perbandingan risiko usaha perikanan rakyat sistem monokultur dan polikultur. Besarnya nilai koefisien variasi menunjukkan besarnya risiko relatif usaha perikanan rakyat. Nilai koefisen variasi yang kecil menunjukkan variabilitas nilai rata-rata tersebut rendah. Hal ini menunjukkan risiko yang dihadapi petambak tersebut rendah, demikian sebaliknya. Risiko usaha yang akan dibahas dalam penelitian ini adalah risiko yang berkaitan dengan risiko biaya, risiko penerimaan dan risiko keuntungan.

Berdasarkan tabel 7, risiko biaya dan penerimaan usaha perikanan rakyat sistem polikultur lebih lebih rendah dibanding monokultur. Hal ini disebabkan oleh tingginya penggunaan variasi biaya dan penerimaan sistem monokultur. Namun, pada perhitungan uji z menunjukkan bahwa tidak berbeda nyata antara risiko biaya dan penerimaan usaha perikanan rakyat sistem monokultur dan polkultur.

Keuntungan memperlihatkan nilai yang diperoleh dari penerimaan dikurangi dengan seluruh biaya yang dikeluarkan dalam melaksanakan usaha perikanan rakyat. Terkadang keuntungan tidak sesuai dengan apa yang diharapkan oleh petambak, sehingga perlu juga diketahui risiko keuntungannya. Risiko keuntungan dianalisis dengan koefisien variasi dan selanjutnya dilakukan perbandingan risiko pendapatan antara usaha perikanan rakyat sistem monokultur dan polikultur.

Tabel 7 menunjukkan bahwa usaha perikanan rakyat sistem monokultur memiliki risiko keuntungan yang tinggi dibandingkan dengan risiko usaha perikanan rakyat sistem polikultur, hal Ini berarti variasi keuntungan usaha perikanan rakyat sistem monokultur lebih tinggi. Risiko keuntungan usaha perikanan rakyat sistem monokultur yang tinggi ini karena penerimaan hanya berasal dari satu sumber 
saja yaitu ikan bandeng, berbeda dengan usaha perikanan rakyat sistem polikultur dimana sumber penerimaan berasal dari dua komoditas, yaitu ikan bandeng dan udang. Perhitungan uji z menunjukkan bahwa nilai risiko keuntungan kedua usaha perikanan rakyat tidak berbeda nyata, hal ini disebabkan karena tidak semua petani tambak meraup keuntungan yang tinggi dengan menerapkan sistem polikultur.

\section{Pembahasan Umum}

Kegiatan operasional usaha perikanan rakyat sebagian besar dilakukan oleh petani penggarap yang telah ditunjuk oleh pemilik lahan dengan kesepakatan komisi atau bagi hasil tertentu. Ada beberapa tahap yang dalam kegiatan usaha perikanan rakyat memerlukan bantuan tenaga kerja seperti pada saat melakukan pemanenan ikan dan udang. Kegiatan pemanenan membutuhkan bantuan tenaga kerja yang berasal dari sesama petani tambak yang sedang tidak sibuk. Petani tambak di Kabupaten Pangkep tergolong kompak dan saling membantu jika petani tambak lainnya mengalami kesulitan dalam melakukan kegiatan operasional.

Modal merupakan salah satu faktor yang harus dipenuhi dalam rangka mengakomodasi kegiatan operasional suatu usaha. Modal diperlukan untuk membeli peralatan (pompa, jala, pukat dan keranjang), benih ikan dan udang, pupuk, pakan, obatobatan, BBM dan upah tenaga kerja. Pada prakteknya, tidak semua petani memiliki peralatan yang memadai utnuk memulai usaha, untuk menjalankan usahanya maka petani petambak meminjam beberapa peralatan ke sesama petani tambak atau ke punggawa pasar lelang. Benih ikan dan udang pun dapat diperoleh dengan cara bekerja sama dengan pengusaha pembenihan atau punggawa pasar lelang, dimana biaya untuk benih ikan dan udang akan dibayarkan setelah panen dengan syarat dan ketentuan yang telah disepakati bersama oleh kedua pihak. Sebagian besar petani tambak lebih memilih menggunakan pakan alami hasil endapan dari pupuk yang digunakan oleh petani. Dengan adanya pakan alami tersebut diharapkan dapat menekan biaya pakan yang bisa saja dikeluarkan oleh petani. Beberapa petani pun menggunakan pakan buatan sebagai pakan tambahan, dengan pakan tambahan tersebut diharpkan ada tambahan asupan nutrisi yang akan diperoleh oleh ikan dan udang yang dibudidayakan.

\section{KESIMPULAN DAN SARAN \\ Kesimpulan}

1. Biaya dan keuntungan usaha perikanan rakyat sistem polikultur lebih besar dibanding dengan usaha perikanan rakyat sistem monokultur dengan biaya masing-masing sebesar Rp 14.722.597 dan Rp 13.191.880 sedangkan keuntungan masingmasing sebesar Rp 10.285.066 dan Rp 6.710.486. Perhitungan statistik menunjukkan bahwa biaya dan 
keuntungan terdapat perbedaan yang nyata antara usaha perikanan rakyat sistem monokultur dan polikultur di Kabupaten Pangkep.

2. Usaha perikanan rakyat sistem polikultur memiliki risiko biaya, risiko penerimaan dan risiko keuntungan lebih rendah dibandingkan dengan usaha perikanan rakyat sistem monokutur dengan besar nilai koefisien variasi (CV) masing-masing sebesar 0,11 ; 0,29 dan 0,56 untuk usaha perikanan rakyat sistem polikultur dan 0,$12 ; 0,37$ dan 0,88 untuk usaha perikanan rakyat sistem monokultur. Walaupun risiko biaya, penerimaan dan keuntungan usaha perikanan rakyat sistem polikutur lebih kecil dibanding dengan sistem monokultur, namun pada perhitungan statistik tidak terdapat perbedaan yang nyata nilai risiko biaya, risiko penerimaan dan risiko keuntungan di antara keduanya.

\section{Saran}

1. Hasil penelitian menunjukkan bahwa usaha perikanan rakyat sistem polikultur lebih menguntungkan dan memiliki risiko usaha kecil dibanding dengan usaha perikanan rakyat sistem monokultur sehingga layak untuk diupayakan pengembangannya dengan syarat dicari upaya untuk menekan risiko usahanya.

2. Pemerintah atau instansi yang terkait sebaiknya lebih serius mendukung usaha perikanan rakyat sistem polikultur untuk dikembangkan, misalnya penyuluhan tentang teknik budidaya polikultur yang benar, bantuan sarana dan prasarana dll.

3. Strategi yang dapat dilakukan untuk meningkatkan keuntungan kedua jenis usaha yaitu dengan melakukan teknik budidaya yang baik dan benar serta meningkatkan benih ikan bandeng dan udang dalam pelaksanaannya

\section{DAFTAR PUSTAKA}

Adi, Sapto. 2011. Analisa Usaha Perikanan Budidaya. Pusat Penyuluhan Kelautan dan Perikanan Kementerian Kelautan dan Perikanan.

Dolorosa, Eva., Masyhuri, Lestari, dan Jamhari. 2014. Analisis Kelayakan Finansial Usaha Perikanan Tambak Polikultur Bandeng - Udang Windu. Jurnal Social Economic of Agriculture (3): 20-36.

Hasan, Iqbal. 2008. Pokok-Pokok Materi Statistik 2. Jakarta: Bumi Aksara

Humamy, H. F. 2013. Analisis Usaha Tambak Polikultur Kepiting - Ikan Nila Di Desa Paluh Manan Kecamatan Hamparan Perak Kabupaten Deli Serdang. Journal on Social Economic of Agriculture and Agribusiness (2): 14-26. 
Imelda, Mulyo, J. H., dan Darwanto, D.

H. 2008. Analisis Perilaku Petani Terhadap Risiko Usahatani Lidah Buaya Di Pontianak. Jurnal Agro Ekonomi (15): 17-34.

KKP. 2014. Kelautan dan perikanan dalam angka 2014. Jakarta: Pusat Data Statistik dan Informasi.

Kordi, M. G. H. 2011. Sukses Memproduksi Bandeng Super. Yogyakarta: Lily Publisher.

Kurniati, Dewi. 2012. Analisis Risiko Produksi dan Faktor-Faktor yang Mempengaruhinya pada Usahatani Jagung di Kecamatan Mempawah Hulu Kabupaten Landak. Jurnal Social Economic of Agriculture (1): 60-68.

Mahmud, U., Sumantadinata, K., dan Pandjaitan, N. 2007. Pengkajian Usaha Tambak Udang Windu Tradisional di Kabupaten Pinrang, Sulawesi Selatan. Jurnal MPI (2): 70-85.

Marban, D., P., Hernandez, J., M., dan Leyva, E., G. 2006. Simulating The Economic Viability of Nile Tilapia and Australian Redclaw Crayfish Polyculture in Yucatan, Mexico. Journal Aquaculture (261): 151159.

Marwiantin, A., Suwarto dan Ani, S. W. 2014. Analisis Komparatif Usahatani Wortel Sistem Monokultur Dengan Sistem Polikultur Di Kelurahan Blumbang, Kecamatan Tawangmangu, Kabupaten Karanganyar. E-Jurnal Agrista Edisi 2 (2): 1-10.

Ramaswami, B., Ravi, S dan Chopra, S. D. 2003. Risk Management in Agriculture. Delhi: Discussion Paper in Economics.

Rifki, M. N. 2014. Analisis Risiko Dan Ketidakpastian Pendapatan Usahatani Jambu Biji Pada Integrated Farming System Dengan Metode Simulasi Monte Carlo [Tesis]. Yogyakarta: Program Pascasarjana Universitas Gadjah Mada.

Yasin, M. 2013. Prospek Usaha Budidaya Udang Organik Secara Polikultur. Jurnal Ilmiah Agriba (1): 86-99. 